Original Research Article

\title{
Impact of lecture delivery by using PowerPoint presentation and black board and chalk in second year MBBS students in Pharmacology
}

\author{
Preetha Jose, Firoz Thaha*, Kavitha Varghese, Aruvi Poomali
}

\begin{abstract}
Department of Pharmacology, Government Medical College, Thrissur, Kerala, India

Received: 17 December 2018

Accepted: 10 January 2019

*Correspondence to:

Dr. Firoz Thaha,

Email: firozthoufeeq@ gmail.com

Copyright: (C) the author(s), publisher and licensee Medip Academy. This is an openaccess article distributed under the terms of the Creative Commons Attribution NonCommercial License, which permits unrestricted noncommercial use, distribution, and reproduction in any medium, provided the original work is properly cited.
\end{abstract}

\begin{abstract}
Background: The use of electronic media and audio-visual aids for teaching has become increasingly common in medical colleges. This teaching method is considered superior to blackboard and chalk by majority of the students and teachers. But the quality of medical education has not drastically improved in comparison. This study compares the impact of lecture delivery using PowerPoint presentation as opposed to blackboard and chalk in medical students attending pharmacology classes.
\end{abstract}

Methods: This was a cross sectional study done in the second year MBBS students attending pharmacology classes in the Department of Pharmacology at Government Medical College, Thrissur in the year 2017. Students were given lectures on two similar topics, one using PowerPoint presentation and the other using blackboard and chalk by the same teacher. The students were given a posttest after each lecture and marks were analysed using Independent student's t test. A feedback was also taken from the students regarding the two lecture delivery methods and the data is expressed in percentages.

Results: This study was done in 149 medical students who attended pharmacology classes. The students scored significantly higher marks in the posttest when the lecture was taken using black board and chalk ( $\mathrm{p}<0.001) .58 \%$ of the students preferred lecture delivery using PowerPoint compared to $38 \%$ preferring black board and chalk. $4 \%$ of the students considered both methods equally good.

Conclusions: Lecture delivery using black board and chalk was found to be more efficacious than power point presentation when the marks of the post-tests were compared. However, majority of the students preferred lecture delivery using power point to blackboard and chalk.

Keywords: Blackboard and chalk, Lecture, Pharmacology, PowerPoint

\section{INTRODUCTION}

The efforts that go into making a doctor can be broken down to two major aspects - diagnostics and therapeutics. This makes the study of Pharmacology quintessential to a medical student's formative years. However, this subject is oft regarded as challenging since it entails memorising the names of various drugs, their mechanisms of action, uses, adverse effects, drug interactions etc. ${ }^{1}$ Understanding and retaining this substantial amount of information demands effort from the student's end. In the same measure, medical educators are compelled to use every teaching weapon at their disposal. Garg et al, has emphasized the importance of lecture classes, as $75 \%$ of the students in this study preferred studying Pharmacology from both lecture notes and text books. ${ }^{2}$ As such, the use of teaching aids for lecture delivery in medical colleges have transitioned from the classical "blackboard and chalk" to audio-visual aids, in particular PowerPoint presentations. The latter is often perceived superior by most students as well as teachers, as pictures and words are more efficacious when they occur simultaneously. ${ }^{3}$ Despite the adoption of technology to facilitate learning, one could question whether this has in fact translated into a proportional improvement in the students' comprehension of a topic and ability to recollect. Examinations help us to quantify this; and whether 
performance during examinations, by virtue of these relatively newer methods, is enhanced is again unclear., ${ }^{4,5}$ Both methods have merits and demerits. This study aims to compare the effectiveness of both lecture delivery methods in medical students attending pharmacology lectures.

\section{METHODS}

This was a cross sectional study conducted in the Department of Pharmacology at Government Medical College, Thrissur during the academic year 2017-18. This study was approved by the Institutional Ethics Committee on $13^{\text {th }}$ January 2017. After taking permission from the Head of the Department of Pharmacology, second year MBBS students attending pharmacology classes during the study period were included in the study. Students who were absent were excluded.

A total of 149 second year MBBS students were given lectures on two similar topics, one using Microsoft PowerPoint presentation and the other using blackboard and chalk by the same teacher. The students were first given lecture using Microsoft PowerPoint presentation and a post test for 10 marks was conducted. Then the students were given lecture using black board and chalk and test for 10 marks was conducted. The marks of the post-test after the two lectures were entered and analysed. A questionnaire was also given to the students after the lecture classes and their feedback was taken. They were asked to identify the teaching methods preferred by them and the reasons for the preference. They were also asked to identify the difficulties encountered with the other teaching method.

\section{Statistical analysis}

Statistical analysis was done using Statistical package for social service (SPSS) software. Independent student's t test was done to analyse the marks obtained following each lecture. Results were tabulated and significance was expressed according to the $\mathrm{p}$ value, $<0.05$ - significant and $<0.001$ - highly significant. Students preferences between the two teaching methods were expressed in percentages.

\section{RESULTS}

Table 1 compares the marks obtained by the students $(n=149)$ in the post-tests conducted after lectures using PowerPoint presentation and blackboard and chalk. The mean value is 6.21 with a standard deviation of 2.15 for chalk and blackboard.

It is only 5.15 with a standard deviation of 2.44 for PowerPoint presentation. Median value is 6.5 for chalk and black board while it is only 5.5 for PowerPoint presentation. Mode is 8 for chalk and black board and it is 7 for PowerPoint presentation. Mean, median and mode is higher for chalk and blackboard compared to PowerPoint presentation.
Figure 1 shows the distribution of marks from 0-10 among the students. $70 \%$ of the students scored $50 \%$ and above marks when taught using chalk and board. Only $56 \%$ of the students scored $50 \%$ and above marks when taught using PowerPoint presentation. This is reflected in this graph. The graph for black board and chalk is more skewed to the right in comparison to PowerPoint presentation, showing that the number of students scoring higher marks is more when taught using blackboard and chalk.

Table 1: Comparison of marks obtained by the students in the post test.

\begin{tabular}{|lll|} 
Parameter & $\begin{array}{l}\text { Blackboard and } \\
\text { chalk }(\mathbf{n}=\mathbf{1 4 9})\end{array}$ & $\begin{array}{l}\text { PowerPoint } \\
(\mathbf{n}=149)\end{array}$ \\
\hline Mean \pm SD & $6.21 \pm 2.15$ & $5.15 \pm 2.44$ \\
\hline Median & 6.5 & 5.5 \\
\hline Mode & 8 & 7 \\
\hline
\end{tabular}

SD - Standard Deviation

Table 2 compares the mean value of the marks obtained after the two lecture delivery methods. The mean value is 6.21 with a standard deviation of 2.15 for chalk and black board and 5.15 with a standard deviation of 2.44 for PowerPoint presentation. When the means were compared using independent students $t$ test the $p$ value is $<0.001$. When the students were taught using blackboard and chalk there was a highly significant increase in the marks compared to PowerPoint presentation.

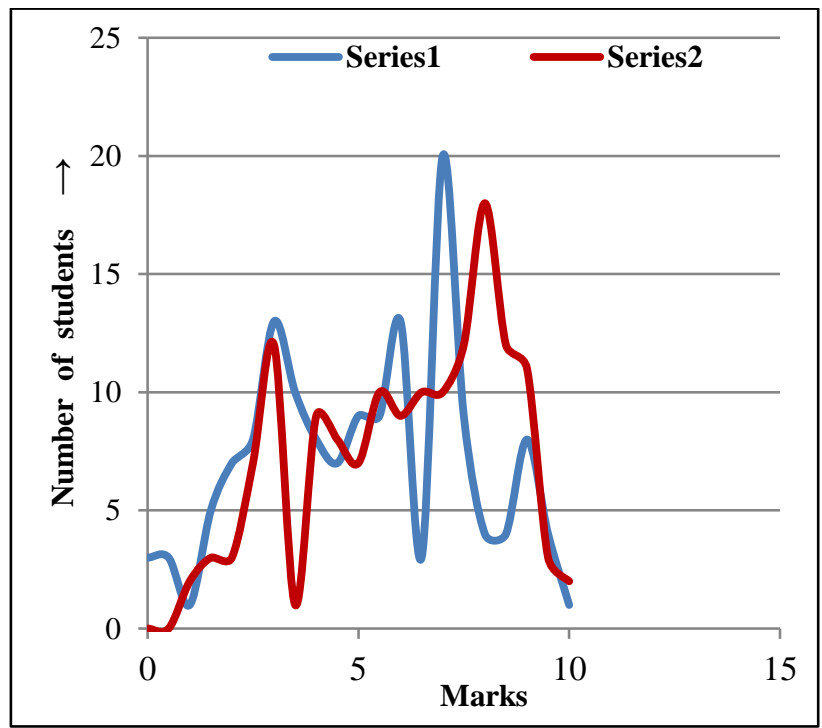

Series 1 - PowerPoint, Series 2 - Chalk and board.

Figure 1: Comparison of marks scored after PowerPoint and chalk and board lecture.

Figure 2 shows the preferences of the students between the lectures using chalk and blackboard and PowerPoint presentation. $38 \%$ preferred blackboard and chalk. $58 \%$ of the students preferred lecture delivery using PowerPoint presentation, which is 1.5 times higher compared to student's preference for chalk and blackboard. $4 \%$ of the students considered both methods equally effective. 
Table 2: Comparison of mean of the marks scored after the two teaching methods.

\begin{tabular}{|lllll|}
\hline Parameter & Blackboard and chalk $(n=149)$ & PowerPoint $(n=149)$ & t value & p value \\
\hline Mean \pm SD & $6.21 \pm 2.15$ & $5.15 \pm 2.44$ & -3.963 & $<0.001$ \\
\hline
\end{tabular}

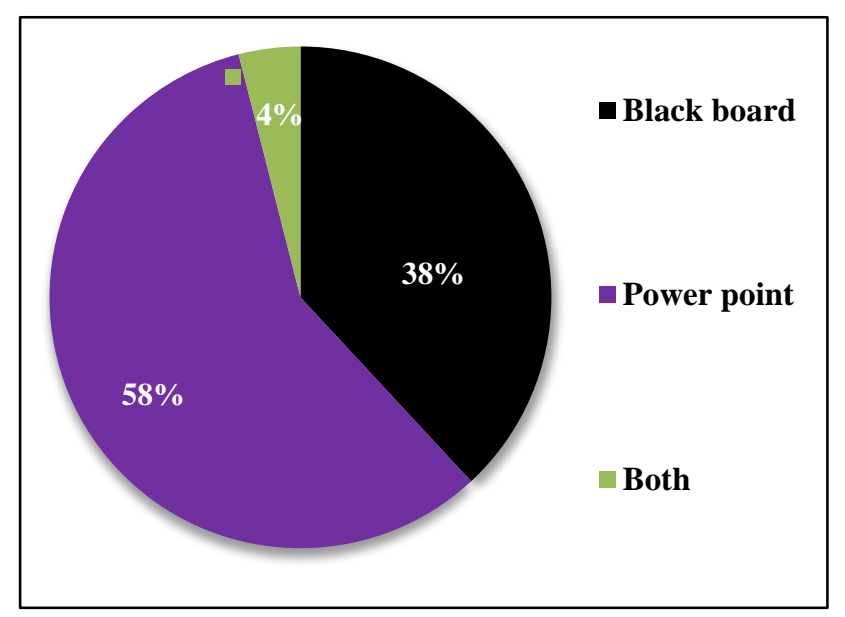

Figure 2: Student's preferences between the two teaching aids.

\section{DISCUSSION}

Effectiveness of a lecture is gauged by how much the students have understood the core concepts and whether they can reproduce the knowledge gained when examined.

In this study $(\mathrm{n}=149)$, the students scored significantly higher marks when taught using blackboard and chalk ( $\mathrm{p}$ $<0.001)$. When a cut-off was placed at $50 \%$ and above marks, $70 \%$ of the students were able to score this when blackboard and chalk were employed. In comparison, only $56 \%$ of the students scored $\geq 50 \%$ marks in the PowerPoint group. This mirrors the results of three previous studies conducted by Vikas Seth et al, Bamne et al, and deSa SB et al, where marks were higher when taught using blackboard. ${ }^{6-8}$ As for the students' preference, more students preferred PowerPoint presentation to blackboard in the study by Seth V et al, and in another study by Ethel LB et al, whereas blackboard was preferred in the studies by Bamne et al, deSa SB et al, and Petimani MS et al. ${ }^{7-10} \mathrm{~A}$ combination of audio-visual aids in lectures was the most preferred teaching methodology in two other studies investigating the same..$^{11,12}$

In present study, there were more students (58\%) preferring PowerPoint presentation to blackboard and chalk (38\%) as per their feedback. In their opinion, PowerPoint presentation was more colourful and visually appealing, and the addition of videos and animations can make the class more interesting. A practical aspect pointed out by $70 \%$ of the students was that they could take down notes more easily, as the writing was clear and visible. But this needs to be viewed cautiously as students may develop a tendency of mechanically copying content from the slides, instead of concentrating on the lecture delivered by the teacher. In a study by Savoy et al, where retention of lecture information with and without PowerPoint was analysed, it was found that students retained $15 \%$ less verbal information delivered along with PowerPoint presentation, eventhough they preferred it over traditional presentations. $^{13}$

Whilst writing on a board, the handwriting of the teacher is an important factor; and it may lack clarity, especially for the students seated at the back of the class. This is often the case for large batches and was experienced during our study as well.

$80 \%$ of the students opined that student-teacher interaction was more with chalk and board lecture. On the other hand, more topics could be covered in a shorter span of time when PowerPoint was used. Nevertheless, $55 \%$ of the students felt that speed of the lecture was adequate with the chalk and board lecture.

In terms of effort required by both the teacher and the student, this was also understandably less with PowerPoint. With the blackboard, students were required to concentrate more, as all the points could not be written with the chalk by the lecturer in between explanations. A lapse in concentration during the lecture could lead to difficulties in grasping the rest of the topic. This kept them more attentive, and $54 \%$ of the students expressed that they could retain more information at the end of the chalk and board lecture. This was also reflected in the post-test, where the marks were significantly higher when taught using blackboard.

\section{CONCLUSION}

Lecture delivery using PowerPoint presentation has its own advantages, and it was the preferred method by majority of the students in this study. It is more visually appealing, and we can offer better diagrams, flow charts and videos to complement our lectures. Interestingly, the students understood the subject matter better and scored more marks when taught using blackboard and chalk, which goes against popular opinion. In the light of this, we suggest that combining the two teaching methods would be more effective than restricting oneself to any one method of lecture delivery. This offers the best of both worlds and can cater to students having different learning styles.

\section{Funding: No funding sources}

Conflict of interest: None declared

Ethical approval: The study was approved by the Institutional Ethics Committee 


\section{REFERENCES}

1. Medical Council of India, Competency based Undergraduate curriculum for the Indian Medical Graduate. 2018;1:136-59.

2. Garg A, Rataboli PV, Muchandi K. Students' opinion on the prevailing teaching methods in pharmacology and changes recommended. Indian J Pharmacol. 2004 May 1;36(3):155-8

3. Mayer RE, Anderson RB. The instructive animation: Helping students build connections between words and pictures in multimedia learning. J Edu Psychol. 1992;84(4):444-52.

4. Bartsch RA, Cobern KM. Effectiveness of PowerPoint presentations in lectures. Computers Education. 2003 Aug 1;41(1):77-86.

5. Kosslyn SM, Kievit RA, Russell AG, Shephard JM. PowerPoint ${ }^{\circledR}$ presentation flaws and failures: a psychological analysis. Fron Psychol. 2012 Jul $17 ; 3: 230$.

6. Seth V, Upadhyaya P, Ahmad M, Kumar V. Impact of various lecture delivery methods in pharmacology. EXCLI J. 2010;9:96-101.

7. Bamne SN, Bamne AS. Comparative study of chalkboard teaching over PowerPoint teaching as a teaching tool in undergraduate medical teaching. Int J Med Sci Public Health. 2016;5(12):2585-7.

8. DeSa SB, Keny MS. PowerPoint versus chalkboard based lectures in pharmacology: evaluation of their impact on medical student's knowledge and their preferences. Int J Adv Health Sci. 2014;1(5):10-4.

9. Novelli EL, Fernandes AA. Students' preferred teaching techniques for biochemistry in biomedicine and medicine courses. Biochem Molecular Biol Education. 2007 Jul;35(4):263-6.

10. Petimani MS, Adake P. Blackboard versus PowerPoint presentation: Students opinion in medical education. Int J Educ Psychol Res. 2015;1(9):289-92.

11. Mohan L, Kamath A, Manish M, Eesha B. Students' attitudes towards the use of audio visual aids during didactic lectures in pharmacology. J Clin Diag Res. 2010;4(6):3363-8.

12. Kumar A, Singh R, Mohan L, Kumar MK. Students' views on audio visual aids used during didactic lectures in a medical college. Asian $\mathrm{J}$ Med Sci. 2013;4(2):36-40.

13. Savoy A, Proctor RW, Salvendy G. Information retention from PowerPoint ${ }^{\mathrm{TM}}$ and traditional lectures. Computers Education. 2009 May 1;52(4):858-67.

Cite this article as: Jose $\mathrm{P}$, Thaha F, Varghese $\mathrm{K}$, Poomali A. Impact of lecture delivery by using PowerPoint presentation and black board and chalk in second year MBBS students in Pharmacology. Int J Basic Clin Pharmacol 2019;8:316-9. 